\title{
Photoacoustic spectra of green and red leaves of ficus Benjamina plant
}

\author{
${ }^{1,2}$ Guskos N., ${ }^{2}$ Majszczyk J., ${ }^{2}$ Typek J., ${ }^{3}$ Rybicki J. and ${ }^{4,5}$ Padlyak B. \\ ${ }^{1}$ Solid State Section, Department of Physics, University of Athens, Panepistimiopo- \\ lis, 15784 Zografos, Athens, Greece \\ ${ }^{2}$ Institute of Physics, West Pomeranian University of Technology, al. Piastów 48, \\ 70-311 Szczecin, Poland \\ ${ }^{3}$ Department of Solid State Physics, Faculty of Applied Physics and Mathematics, \\ Gdansk University of Technology, ul. Narutowicza 11/12, 80-233 Gdańsk, Poland \\ ${ }^{4}$ Spectroscopy Sector, Institute of Physical Optics, Dragomanov St. 23, 79-005 \\ Lviv, Ukraine \\ ${ }^{5}$ Division of Spectroscopy of Functional Materials, Institute of Physics, University \\ of Zielona Góra, ul. Szafrana 4a, 65-516 Zielona Góra, Poland
}

Received: 04.03.2012

\begin{abstract}
Tissue samples of a ficus Benjamina plant are prepared in the shape of thick film for photoacoustic spectroscopy studies. Two absorption bands in the electromagnetic photoacoustic (PA) spectrum are detected in the visible range. They are peaked at about 398 and $670 \mathrm{~nm}$ for a green leaf, and 544 and $570 \mathrm{~nm}$ for a red leaf. The absorption bands detected in the ultraviolet range are attributed to $\pi \rightarrow \pi^{*}$ and $\pi \rightarrow n$ charge transfer transitions. The visible PA spectra strongly depend on the processes responsible for colouring of leaves. The absorption band at $670 \mathrm{~nm}$ could be related to photosynthesis. The absorption band observed at $398 \mathrm{~nm}$ for the green leaf disappears for the red one, though a different band located at $544 \mathrm{~nm}$ appears. The absorption spectra measured in this work are closely similar to those obtained earlier for the other living organisms. The absorption band near $544 \mathrm{~nm}$ is close to that found for spermidine, which is important in the information transfer to DNA. The results obtained in this work confirm experimentally that the red leaves absorb particularly strongly in that spectral region of solar radiation, which is intensely radiated in autumn.
\end{abstract}

Keywords: photoacoustic spectroscopy, ficus Benjamina plant, electronic transitions.

PACS: $78.20 . \mathrm{Pa} ;$ 87.50.cf.

UDC: $535.2,577$

\section{Introduction}

Photoacoustic spectroscopy (PAS) is an important method for investigating materials because it provides the information on the electronic structure, using electromagnetic and acoustic waves and photon-phonon interactions. It is especially useful while non-invasively investigating bioorganic matter and different in vivo processes [1-8].

At the present time radiation processes responsible for the spectral features in the region of $500 \div 600 \mathrm{~nm}$ are still not fully understood, and their role in the biological processes occurring in living matter needs further investigations. In our previous works the mechanisms responsible for channel selector in the metabolic processes have been suggested [8,9]. The copper (II) complexes (mainly spermidine) have been shown to be responsible for information transfer to DNA [10]. The 
ions from the transition groups form complexes with extended wave functions involved in the $d-d$ transitions among the ground and exited states. The PAS has evidenced a presence of very intense $\pi \rightarrow \pi^{*}$ and $\pi \rightarrow n$ electron charge-transfer transitions and weaker $d$-d-transitions in the greenyellow region of visible electromagnetic spectrum [11-13]. Probably, the transfer of information to DNA is different in the excited state and the radiation processes in this region could work as a channel selector [9]. The second suggestion has been to consider the question whether this radiation could act like a 'spark' and provide energy for different metabolic processes [8]. In particular, the PAS has demonstrated that the absorption band peaked at about $470 \mathrm{~nm}$ (similar as in hematite) is peculiar for the living mater $[7,8,14,15]$. It would be interesting to search for a similar absorption band in plants. One can notice in this respect that human vision is the most sensitive just in the yellow-green spectral range (e.g., the peak sensitivity of human eyes lies near $560 \mathrm{~nm}$ ).

The aim of the present report is to investigate the tissues of ficus Benjamina leaves in the green and yellow regions, using the PAS. We have also expected that some other spectral features of the photoacoustic (PA) response should be visible due to photosynthesis.

\section{Experimental}

The leaves of ficus Benjamina plant were collected in November 2009 at the campus of University of Athens (see Fig. 1). Thick-film samples of both green and red leaves of ficus Benjamina tissues were prepared for the PAC. The PA spectra were measured at the room temperature, using common equipment comprising a light source with the power of $1 \mathrm{~kW}$ and a xenon arc lamp with a $0.25 \mathrm{~m}$ ORIEL monochromator (the bandpass width being $5 \mathrm{~nm}$ at $500 \mathrm{~nm}$ ). To reduce lowfrequency noise, signal bandwidth was narrowed using lock-in detection. Namely, a light output from the monochromator was mechanically chopped at the frequency of $10 \mathrm{~Hz}$. The acoustic signal was detected by a very sensitive microphone TREVIE M27 attached to a PA cell.

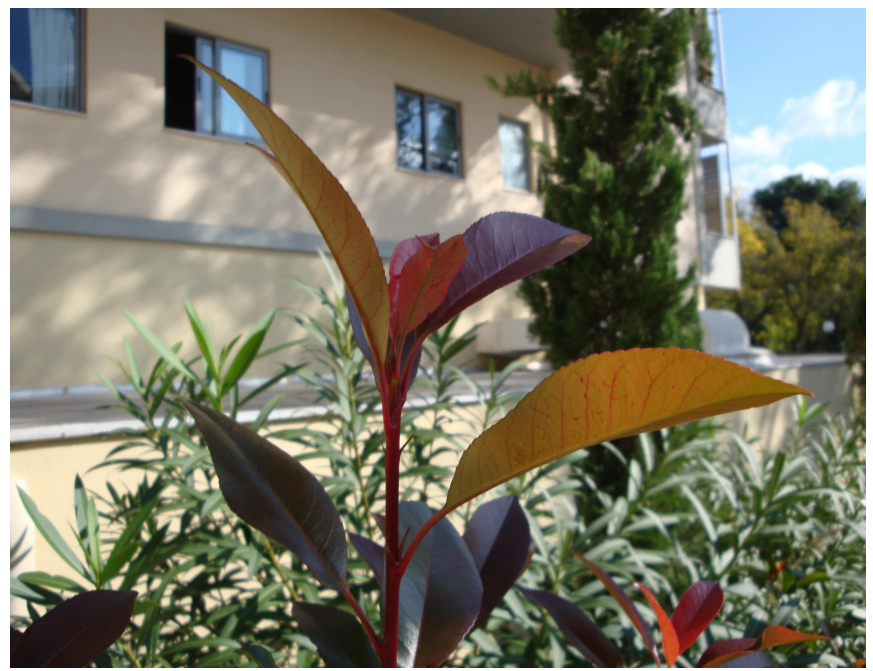

Fig. 1. Ficus Benjamina plant (November, 2009, the University of Athens Campus).

A dual Stanford Research SR830 lock-in amplifier recorded the amplitude and the phase of the microphone signal relative to the input excitation. While averaging over 20 modulation periods, the signal-to-noise ratio was at least 50 for the most of wavelengths of incident light, thus yielding an approximately five-fold improvement over the non-modulated case. All the data were perfectly reproducible. The raw amplitude and phase of the sample signal were normalized against the PA spectrum of a graphite blackbody reference, in order to correct the data for modulationfrequency dependence of thermal diffusion length [16].

Ukr. J. Phys. Opt. 2013, Volume 14, Issue 2 


\section{Results and discussion}

Fig. 2 shows the PA spectra of the green and red ficus Benjamina leaves. Very intense PA bands originating from the $\pi \rightarrow \pi^{*}$ and $\pi \rightarrow n$ charge-transfer transitions dominate below $300 \mathrm{~nm}$. In the visible range, we observe the peak near $398 \mathrm{~nm}$ for the green leaves and that located near $544 \mathrm{~nm}$ for the red leaves. The absorption band located in the red region at about $670 \mathrm{~nm}$ could be seen for the both samples. According to [3], the red absorption band peaked at about $670 \mathrm{~nm}$ could be connected with photosynthesis processes.

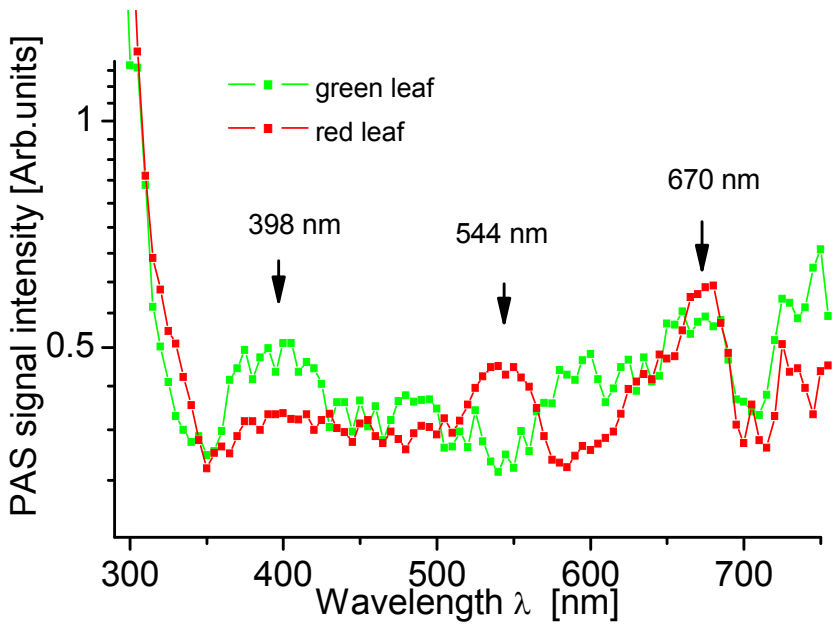

Fig. 2. Photoacoustic spectra of green and red leaves of ficus Benjamina.

It is known that a heat generated through nonradiative transitions in the leaf tissue could produce the PA signal. This heat represents a result of absorption of the intensity-modulated incident light. The intensity of the PA spectrum may be described by the following relation [16]:

$$
I=\gamma k A_{a b s},
$$

where $\gamma$ is a coefficient related to thermal properties and spectrometric characteristics of a sample, $k$ the probability of nonradiative transition from the excited state, and $A_{a b s}$ the absorbance of the sample. The radiative and nonradiative electronic transitions appear due to excitation by external photons. These transitions could produce another photons and phonons. Then the phonons stimulate acoustic responses in the leaf tissue. The nonradiative processes give rise to the PA signal from the localized atomic and molecular states. It is generally acknowledged that the specific ions from the transition metal group, e.g. copper (II), iron (II) and iron (III), could play a very important part in different processes occurring in the living matter.

In the visible region a very broad and intense PA spectrum with the maximum at about $570 \mathrm{~nm}$ is observed for some living organisms (e.g., Trunculariopsis Trunculus, Sea Urchin, and Asterias Rubens [8, 17, 18]). Deconvolution of the PA spectra of the copper (II) complexes of spermidine reveals a fine structure arising from interaction with the crystal field [11-13]. The constituent lines could be centred between 540 and $590 \mathrm{~nm}$. It is suggested that the absorption band observed at $544 \mathrm{~nm}$ for the red leaves of ficus Benjamina could arise from the electronic $d-d$ transitions in some ion belonging to the $3 d$ transition group. Disappearance of the absorption band peaked at about $398 \mathrm{~nm}$ for the green leaves suggests that some radiation processes occur at higher wavelengths and, correspondingly, lower photon energies, although these processes could become more intense. The yellow-green solar radiation becomes more intense in autumn and it might be more advantageous for a plant to obtain energy from this particular region. 
The heat energy gained from the PA processes could be estimated as

$$
\Delta E=h \lambda_{\text {yellow-green }}-h \lambda_{\text {red }}=\frac{h c}{\lambda}-\frac{h c}{\lambda^{\prime}} \cong 3 \times 10^{-24} \mathrm{~J},
$$

where $h$ denotes the Planck constant, $c$ the vacuum light velocity, while $\lambda$ and $\lambda^{\prime}$ are the wavelengths of respectively yellow-green and red radiation. If one calculates a sum for all the cells available in a leaf, it can produce an essential energy dose via the processes involving the ground and excited states of the $3 d$ complexes.

The results obtained here and concerned with observation of the reaction of photoacoustic $d-$ $d$ electronic transitions in biological systems, both in living beings as well as in plants, which occur at very similar electromagnetic wavelengths, suggest an important role of the latter in these processes.

\section{Conclusions}

The tissues of both green and red leaves of the ficus Benjamina plant show the PA response in the two different regions of visible radiation range, at about 398 and $544 \mathrm{~nm}$, respectively. This important result may suggest that the $d-d$ electronic transitions play a significant part in different processes occurring in the living matter, which are influenced by various seasonal effects. It can be more advantageous for a plant to use the solar radiation of longer wavelengths during the autumn than that of shorter wavelengths during the summer. Additionally, the PA responses from the photosynthesis processes are observed for the both green and red leaves.

\section{References}

1. Bults G, Horwitz B A, Malkin S and Canen D, 1982. Photoacoustic measurements of photosynthetic activities in whole leaves. Photochemistry and gas exchange. Biophys. Acta. 679: 452-465.

2. Buschmann C, Prehn H and Lichtenthaler H, 1984. Photoacoustic spectroscopy (PAS) and its application in photosynthesis research. Photosynth. Res. 5: 29-46.

3. Kojlma H, Tawata M, Takabe T and Shimoyama H, 2000. Photosynthetic activity measurement of plants using photoacoustic spectroscopy combined with confocal scanning microscopy. IEICE Trans. Electron., E83-C: 1142-1148.

4. $\mathrm{Wu} \mathrm{R}$ and $\mathrm{Su} \mathrm{Q}, 2001$. A study of intramolecular energy relaxation processes of rare earth complexes [Ln(TTA) $\left.)_{3} \cdot 2 \mathrm{H}_{2} \mathrm{O}, \mathrm{Ln}=\mathrm{Nd}, \mathrm{Eu}, \mathrm{Gd}\right]$. J. Mol. Struct. 559: 195-199.

5. Yang Y and Zhang S, 2003. Photoacoustic spectroscopy study of neodymium complexes with alanine, valine, phenylalanine and tryptophan. Spectrochim. Acta A. 59: 1205-1212.

6. Yang Y and Zhang S, 2003. Photoacoustic spectroscopy study on the co-fluorescence effect of $\mathrm{Eu}^{3+}-\mathrm{La}^{3+}-\mathrm{Hba}$ solid complexes. J. Phys. Chem. 64: 1333-1337.

7. $\mathrm{Yu} \mathrm{X}$ and $\mathrm{Su} \mathrm{Q}, 2003$. Photoacoustic and luminescence properties study on energy transfer and relaxation processes of $\mathrm{Tb}(\mathrm{III})$ complexes with benzoic acid. Photochem. Photobiol. A. 155: 73-78.

8. Guskos N, Aidinis K, Papadopoulos G J, Majszczyk J, Typek J, Rybicki J and Majszczyk M, 2008. Photoacoustic response of active biological systems. Opt. Mater. 30: 814-816.

9. Guskos N, Papadopoulos G, Majszczyk J, Typek J, Wabia M, Likodimos V, Paschalidis D G, Tossidis I A and Aidinis $\mathrm{K}, 2003$. Charge transfer and $f-f$ transitions studied by photoacoustic spectroscopy of $\left[\mathrm{R}\left(\mathrm{NO}^{3}\right)^{2}(\mathrm{PicBH})^{2}\right] \mathrm{NO}^{3}$ and $\left[\mathrm{R}\left(\mathrm{NO}^{3}\right)^{3}(\mathrm{PicBH})^{2}\right]$ complexes $(\mathrm{R}$ - rare earth ion). Acta Phys. Polon. A. 103: 301-313.

Ukr. J. Phys. Opt. 2013, Volume 14, Issue 2 
10. Lomozik L and Gasowska A, 1998. Complexes of copper(II) with spermine and non-covalent interactions in the systems including nucleosides or nucleotides. J. Inorg. Biochem. 72: 37-47.

11. Guskos N, Papadopoulos G P, Likodimos V, Mair G L R, Majszczyk J, Typek J, Wabia M, Grech E, Dziembowska T and Perkowska T A, 2000. Photoacoustic detection of $d-d$ transitions and electronic structure of three polyamine copper complexes. J. Phys. D: Appl. Phys. 33: $2664-2668$.

12. Guskos N, Papadopoulos G P, Likodimos V, Majszczyk J, Typek J, Wabia M, Grech E, Dziembowska T., Perkowska T A and Aidinis C, 2001. Electronic structure of polycrystalline polyamine copper dinitrate complexes investigated by photoacoustic and electron paramagnetic resonance spectroscopy. J. Appl. Phys. 90: 1436-1441.

13. Guskos N, Typek J, Majszczyk J, Maryniak M, Grech E and Kołodziej B, 2007. Photoacoustic and EPR studies of two copper (II) complexes with spermidine analogues. Rev. Adv. Mat. Sci. 14: 97-103.

14. Guskos N, Papadopoulos G P, Likodimos V, Patapis S, Yarmis D, Przepiera A, Przepiera K, Majszczyk J, Typek J, Wabia M, Aidinis K and Drazek Z, 2002. Photoacoustic, EPR and electrical conductivity investigations of three synthetic mineral pigments: hematite, goethite and magnetite. Mat. Res. Bull. 37: 1051-1061.

15. Guskos N, Typek J, Papadopoulos G P, Wabia M, Majszczyk J, Anagnostakis E A and Maryniak M, 2004. The role of visible electromagnetic radiation in intermolecular energy transfer in the rare earths (III) and transition metal complexes in the living system. Mol. Phys. Rep. (Poland). 39: 66-78.

16. Papadopoulos G J and Mair G L R, 1992. Amplitude and phase study of the photoacoustic effect. J. Phys. D: Appl. Phys. 25: 722-726.

17. Guskos N, Papadopoulos G P, Majszczyk J, Typek J, Rybicki J, Guskos A, Kruk I, Aidinis K and Zolnierkiewicz G, 2010. Photoacoustic response of sea urchin tissue. Rev. Adv. Mat. Sci. 23: 76-79.

18. Guskos N, Majszczyk J, Typek J, Rybicki J and Padlyak B, 2013. Photoacoustic response of a common starfish tissue. Ukr. J. Phys. Opt. 14: 44-49.

Guskos N., Majszczyk J., Typek J., Rybicki J. and Padlyak B., 2013. Photoacoustic spectra of green and red leaves of ficus Benjamina plant. Ukr.J.Phys.Opt. 14: 96 - 100.

Зразки тканини фікуса Бенджаміна були приготовлені у вигляді товстих плівок для дослідження фотоакустичних спектрів. У видимій області спектру були виявлені дві фотоакустичні смуги поглинання при 398 і 670 нм для зелених листків та при 544 і 570 нм - для червоних. Смуги поглинання виявлені в ультрафіолетовому діапазоні спектру відносяться до $\pi \rightarrow \pi^{*} i \pi \rightarrow n$ переходів з переносом заряду. Фотоакустичні спектри у видимій області залежать від проиесів, які відповідають за забарвлення листків. Смуга поглинання при 670 нм могла б відповідати фотосинтезу. Смуга поглинання, яка спостерігається при 398 нм для зелених листків зникає - у червоних, хоча виникають інші смуги, локалізовані при 544 нм. Спектри поглинання, отримані в иій роботі $\epsilon$ досить подібними до спектрів, отриманих раніше для інших живих організмів. Смуга поглинання в околі 544 нм близька до виявленої в спермідині, який відіграє важливу роль в передачі інформації ДНК. Результати отримані в иій роботі експериментально підтверджують те, щзо червоні листки поглинають світло сильніше у тому спектральному діапазоні сонячного випромінювання, який інтенсивніше випромінюється восени. 